\title{
A economia política da política monetária no Primeiro Governo Dilma: uma análise sobre taxa de juros, convenção e rentismo no Brasil *
}

\author{
Giordanno Nader **
}

\begin{abstract}
Resumo
O presente artigo busca, por meio de um estudo de economia política, aprofundar na análise da condução política monetária do primeiro governo Dilma Rousseff, com ênfase especial para o comportamento da taxa de juros. Com base nas teses sobre dominância financeira da economia política (pós) keynesiana, sobretudo no que concerne aos conceitos de convenção e rentismo, sustenta-se que a redução da taxa nominal de juros acompanhada de uma inflação persistente resultou em um nível de taxa de juros reais abaixo do nível convencionalmente aceito pela população. A partir daí, os setores mais interessados na manutenção da convenção, os setores rentistas e financistas, no afã de retomar o patamar de rentabilidade real, passaram a se organizar em desfavor da política econômica como um todo. Argumenta-se ainda a formação de um processo retroalimentado na economia brasileira, no qual a reação organizada destes setores de oposição resultara no agravamento da crise econômica e política, que por sua vez, fornecera cada vez mais a substância para a atuação destes setores.
\end{abstract}

Palavras-chave: Economia política; Política monetária; Taxa de juros; Convenção; Rentismo.

\begin{abstract}
The political economy of monetary policy in Dilma Roussef's government's: an analysis of interest rates, convention and rent-seeking in Brazil

This article seeks to understand, through an analysis of the political economy, the limitations of Dilma Rousseff's government's monetary policy, with an emphasis on the trajectory of interest rates. Based on the convention thesis (in the Keynesian sense) and focusing on the concepts of financial dominance and rent seeking of the (post) Keynesian political economy, it is argued that there was an attempt to reduce the interest rate (nominal and real) below a level conventionally accepted by the population. From there, the sectors concerned with the maintenance of the convention, specifically the rent seeking financial sector, began to organize themselves in disfavor of economic policy as a whole. It is also argued that a short-term vicious circle in the Brazilian economy formed, in which the reaction of these opposition sectors resulted in deepening economic and political crisis, which, in turn, improved the performance of these sectors.
\end{abstract}

Keywords: Political economy; Financialization; Monetary policy; Interest rates; Convention; Rent seeking.

JEL B22, B59, E20, E52, E58, E60.

\footnotetext{
* Artigo recebido em 30 de setembro de 2016 e aprovado em 28 de julho de 2017. O autor agradece ao professor Doutor Antonio Corrêa de Lacerda pelas críticas, discussões e orientações, eximindo-o evidentemente de qualquer responsabilidade por eventuais erros ou omissões contidos neste trabalho.

${ }^{* *}$ Doutorando no Programa de Pós-graduação em Economia da Universidade Federal Fluminense (PPGE/UFF), Niteroi, RJ, Brasil. E-mail: giordannonader@hotmail.com.
} 


\section{Introdução}

A gestão de política econômica do primeiro governo de Dilma Rousseff (2011-2014) ainda sucede uma discussão bastante plural e não consensual entre os especialistas. Um dos eixos mais categóricos desta discussão é a condução da política monetária, notadamente a política de juros. A trajetória da taxa básica de juros (Selic) para o período analisado, quando examinada em particular, é bastante controversa, o que reforça a falta de consenso. O Banco Central, a partir do segundo semestre de 2011, dá início a um movimento de queda contínua da Selic, até esta alcançar 7,25\% ao ano em outubro de 2012, permanecendo neste piso histórico por durante seis meses. A partir de abril de 2013, inicia-se uma reversão não tão gradual, sendo que ao final de 2014 a Selic encontrava-se em níveis superiores aos verificados em janeiro de 2011.

A redução da taxa de juros, no entanto, deve ser apreendida não a partir de uma mera "canetada" dos policy makers, mas sim como parte integrante de uma ampla tentativa de alteração na orientação de política macroeconômica brasileira, que visava uma flexibilização da rigidez imposta pelo tripé macroeconômico ${ }^{1}$. Esta "nova política", denominada pelo próprio Ministro da Fazenda, Guido Mantega, de Nova Matriz Macroeconômica, visava, em linhas gerais, além do afrouxamento da política monetária, um patamar de taxa de câmbio mais competitivo e uma política fiscal "amigável ao investimento"2. No médio prazo, estas medidas tinham por objetivo corrigir alguns parâmetros macroeconômicos descoordenados pelo regime econômico vigente, tais como as elevadas taxas de juros, a sobreapreciação cambial crônica, o regime fiscal bastante rígido, uma perda estrutural de dinamismo da indústria nacional, dentre outros. Mas também, a Nova Matriz contemplava também um elemento de curto prazo, o de fornecer estímulos à demanda doméstica que dava sinais de desaquecimento nesse momento.

Sobre o regime de metas de inflação, em singular, diversos estudos heterodoxos têm criticado a sua excessiva rigidez e tentado entender os motivos que fazem as taxas reais de juros no Brasil serem as mais elevadas do planeta. A análise comparativa com outros países do porte da economia brasileira e que atuam sob metas inflacionárias permite concluir que as taxas de juros brasileiras são, de fato, uma verdadeira "jabuticaba". Desde 1995, taxas de juros "normais" em relação aos demais países foram verificadas apenas entre o final 2012 e meados de 2013, quando

(1) O tripé da política macro corresponde ao regime de metas de inflação para a estabilidade econômica, o regime de megassuperávits primários para a disciplina fiscal, e um câmbio flutuante para acomodar choques externos.

(2) É verdade que as políticas anticíclicas adotadas entre 2009 e 2010 para enfrentar a crise financeira internacional, centradas principalmente em taxas de juros mais baixas, relaxamento fiscal, expansão do crédito e redução do compulsório, obrigaram uma primeira flexibilização da rigidez da política macroeconômica desde a implementação do “tripé”. No entanto, foi no governo Dilma que esse processo se aprofundou. 
a Selic alcançou o vale de sua trajetória no período analisado e o IPCA rondava o teto da meta inflacionária.

Além da redução da taxa de juros, o governo diversificou o conjunto de instrumentos de política monetária e ampliou em larga escala a provisão de crédito, ao lançar mão dos bancos públicos. Numa análise ex-post, a inflexão na trajetória da Selic verificada a partir de 2013 pode refletir tanto o fraquejo das políticas adotadas em atingir os objetivos propostos no plano econômico, quanto as dificuldades em se promover uma redução dos juros no Brasil no plano estrutural. A maior parte das explicações que tenta dar conta dos motivos do refreamento do esforço de flexibilização da política monetária neste período, inclusive a retórica oficial do governo, é feita a partir de um viés puramente economicista. Neste sentido, destacam alguns fatores macroeconômicos internos, como a inflação resistente, a redução no nível da atividade econômico, o caráter limitado da política expansionista em função do compromisso com o equilíbrio orçamentário e a estabilidade econômica, dentre outros; e alguns fatores externos como os desdobramentos da crise internacional a partir de 2011, sobretudo o aprofundamento da crise da Zona do Euro, a lenta recuperação da economia mundial e a desaceleração gradual da China.

Este artigo propõe-se a apresentar um argumento que pode vir a somar a estes descritos acima: o de que os resultados limitados da política monetária do governo Dilma podem ser explicados a partir da organização e atuação dos setores rentistas e financistas em desfavor da política econômica como um todo. Assim, é de fundamental importância adentrar no seio da economia política para conceber de que forma este processo se desenrolou. O trabalho insere-se numa linha de pesquisa que tem ganhado força no Brasil, denominada de Economia Política da Política Monetária ${ }^{3}$.

Baseando-se nos conceitos de rentismo e convenção econômica, ambos no sentido keynesiano do termo, e considerando a existência de uma convenção na economia brasileira em torno da manutenção da taxa de juros reais em patamares elevados, o intuito aqui é analisar de que forma os setores interessados no pagamento de juros elevados podem ser responsáveis pela limitação da política econômica, bem como quais as suas formas de organização e de atuação. Dois pontos são considerados a priori. De um lado, a drástica redução das taxas reais de juros abaixo do "nível convencionalmente aceito", implicava uma perda dos rendimentos reais para os setores rentistas e financistas. De outro, a concorrência dos bancos públicos

(3) O termo Economia Política da Política Monetária encontra uma tradução literal na literatura internacional, a Political Economy of Monetary Policy, mas os sentidos podem ser diferentes. De modo geral, a Political Economy of Monetary Policy tem seu foco central para os fatores políticas que interferem na decisão autônoma e independente do Banco Central norte-americano. Já o termo Economia Política da Política Monetária aqui empregado para o caso do Brasil, tal qual em Modenesi (2013), é focado nas relações políticas e econômicas que torna a política monetária rígida e favorece alguns setores econômicos em detrimento de outros. 
forçava os bancos privados a seguirem o mesmo caminho, isto é, reduzirem os seus elevados spreads bancários e aumentarem o montante de operações. Ao sentirem-se lesados, organizaram-se no intuito de impelir as autoridades do governo a recuarem em prol da manutenção da convenção estipulada sobre a taxa de juros.

Além desta introdução, o trabalho é dividido em cinco partes. A primeira seção apresenta o aparato teórico, a economia política (pós) keynesiana. A segunda descreve de que forma, a partir do regime de política monetária vigente, formou-se uma convenção da taxa de juros na economia brasileira. A terceira apresenta uma visão geral da política monetária do governo Dilma. A quarta discute as formas de influência e de atuação dos setores rentistas e financistas em prol da manutenção da convenção no período recortado. A última as considerações finais do trabalho.

\section{A economia política (pós) keynesiana: da não-neutralidade do dinheiro à não- neutralidade das decisões de política monetária}

Keynes, em sua obra maior, a Teoria Geral do Emprego, do Juro e da Moeda (1936), pretendia demonstrar ao pensamento liberal hegemônico da época, que a intervenção estatal na economia, por meio de políticas econômicas, poderia ser útil para alavancar os níveis de emprego e renda, gravemente comprimidos pela Crise de 1929. O marco teórico keynesiano nasce, portanto, do âmago da crítica aos principais axiomas neoclássicos, tais como, a dicotomia clássica, a teoria quantitativa da moeda, a teoria dos fundos emprestáveis, a eficiência alocativa dos mercados produtivos e financeiros, dentre outros. Não obstante as diversas releituras e reinterpretações da contribuição de Keynes, convencionou designar de economia política keynesiana o aporte teórico mainstream que baseou a política macroeconômica da maior parte das economias capitalistas nos chamados "trinta anos gloriosos".

Esta, inclusive, parece ser a crítica daqueles economistas que afirmam que os desenvolvimentos posteriores que se denominavam keynesianos foram se afastando cada vez mais do pensamento desenvolvido por Keynes, sendo que a verdadeira hegemonia no âmbito teórico (e prático) neste período foi dada pelos modelos keynesianos-neoclássicos da Síntese Neoclássica. A vertente póskeynesiana desenvolve-se com o propósito de resgatar o pensamento original de Keynes, encarregando-se de afastar qualquer tipo de má compreensão que o circunda e também de avançar nas lacunas deixadas pelo autor. $O$ resgate se centra principalmente na retomada do conceito amplo de uma economia monetária. Ao definir a economia capitalista como uma "economia monetária de produção", Keynes desejava evidenciar a impossibilidade de se analisar separadamente os fenômenos monetários e reais. Isso porque, em primeiro plano, está a ideia de que o "dinheiro importa" (money matters), representando o elo que conecta o lado real (produtivo) ao lado monetário. Nesta perspectiva, o dinheiro não é neutro, isto é, não 
é apenas um meio para as trocas, podendo significar também um fim nele mesmo, de acordo com as decisões de aquisição de ativos dos agentes econômicos. Como qualquer outro ativo, o dinheiro possui demanda e influencia o lado real da economia, por meio das decisões de produção e investimento (Keynes, 1985).

Assim, em um ambiente não-ergódico, os agentes podem, em qualquer momento do ciclo econômico, manter suas riquezas na forma líquida no portfólio de aquisição de ativos. É justamente a ignorância acerca do futuro que leva os agentes, como forma de prevenção, a reterem dinheiro, o que realmente não faz sentido quando se pensa pela ótica do equilíbrio neoclássico (Wray, 2006). E são os atributos de liquidez universal e reserva de valor ${ }^{4}$ que fazem do dinheiro uma garantia contra a incerteza fundamental.

Keynes, no Treatise of Money, introduziu a concepção de dois circuitos distintos que interagem para fazer ver de que modo ocorre a conexão entre o lado real e o lado monetário numa economia monetária de produção. De acordo com o autor, existe uma dicotomia entre dois circuitos de circulação monetária: a circulação industrial e a circulação financeira ${ }^{5}$. No circuito industrial, a moeda é unicamente destinada às transações e, portanto, compatível com a teoria quantitativa da moeda (TQM). Contudo, na circulação financeira, onde nem toda moeda é destinada à transação de bens e serviços, o equilíbrio estático da TQM fica comprometido. A possibilidade de reter riqueza financeira por tempo indefinido, como ocorre neste circuito, promove um descolamento entre a circulação financeira e a de bens, fazendo com que a velocidade de circulação e a quantidade de transações variem consideravelmente, seja no curto ou no longo prazo, ao contrário do que apregoa a relação proporcional contida na Equação de Fisher (Keynes, 1930; Carvalho et.al., 2012).

Esta possibilidade de retenção de riqueza líquida é explicada dentro do pensamento keynesiano pela teoria da preferência pela liquidez (PPL). Em particular, a PPL é o ponto principal da crítica à teoria dos fundos emprestáveis (TFE), seja no que diz respeito à formação da taxa de juros, seja nos determinantes do montante de investimento e de emprego. De acordo com a PPL, a taxa de juros é um fenômeno monetário que expressa um prêmio pela renúncia à liquidez imediata por um determinado período, e não uma compensação à abstenção de consumo presente vide TFE. Em outras palavras, é o desejo dos agentes em manterem suas riquezas na forma líquida que determina a taxa de juros (Keynes, 1985). A teoria da taxa de juros em Keynes pode ser melhor compreendida a partir teoria precificação

(4) Sob as funções de meio de pagamento e unidade de conta, o dinheiro de fato se torna um simples véu de trocas. No entanto, ao poder preservar o valor presente e transportar para o futuro, ele se torna um ativo elementar no processo de decisão futura dos agentes.

(5) $\mathrm{O}$ primeiro circuito refere-se à circulação de bens. $\mathrm{O}$ segundo refere-se às operações com ativos financeiros, com a moeda não sendo apenas meio circulante, mas também objeto de retenção (Keynes, 1930). 
de ativos ${ }^{6}$ proposta no Capítulo 17 da TG. Por meio desta generalização, a determinação da taxa de juros repercute nos preços dos ativos. Toda mercadoria possui uma taxa própria de juros em função do retorno esperado dela mesma, e estas taxas podem ser expressas em termos de dinheiro, que, por sua vez, possui a maior taxa de juros em torno de si mesmo (Keynes, 1985; Wray, 2006). A taxa monetária de juros recebe uma atribuição privilegiada em relação às demais, o que a torna mais resistente à baixa do que as taxas de juros específicas dos outros bens. Esta relutância à queda deve-se a algumas características especiais de escassez do dinheiro, que faz deste um ativo preferível ${ }^{7}$. Além disso, a demanda por moeda ${ }^{8}$ pode variar significativamente de acordo com cada estágio do ciclo. Por isso, a preferência pela liquidez (e a velocidade de circulação de moeda) não é constante, mas sim altamente instável.

No entanto, Keynes observou que a taxa de juros tende a ser estável por um determinado período. Para explicar tal fato, o autor parte para a ideia de convenção ${ }^{9}$, introduzida brevemente na TG e aprofundada no seu artigo de 1937, publicado no Quartely Journal of Economics, segundo a qual, de maneira geral, os agentes supõem - em razão da incerteza fundamental - que a situação econômica vigente deve permanecer por tempo indefinido, mesmo que isso não tenha nenhuma base lógica. Desta forma, os agentes ignoram, em boa parte, as perspectivas sobre as mudanças futuras, dando ênfase à condição presente (Keynes, 1937). A ideia de convenção é expandida para o comportamento especulativo que determina a taxa de juros que remunera os títulos de longo prazo e a preferência pela liquidez, colocandoas como conceitos psicológicos, em que os agentes determinam convencionalmente um nível considerado seguro para as taxas de juros. Nas palavras do autor: "qualquer taxa de juros aceita com suficiente convicção como provavelmente duradoura será duradoura; sujeita, naturalmente, em uma sociedade em mudança a flutuações originadas por diversos motivos, em torno do nível normal esperado" (Keynes, 1982, p. 144).

Desde a década de 1980, alguns autores têm retomado o desenvolvimento teórico do conceito de convenção econômica. Não somente, estes autores também perseguem a aplicabilidade deste conceito para a determinação da taxa de juros.

(6) A fórmula da precificação dos ativos que mede o retorno monetário (r) é $q$ - $c+l+a$, em que $q$ representa a "taxa esperada de quase-renda"; $c$ diz respeito aos custos de estocagem, manutenção e carregamento do ativo em questão; 1 representa a liquidez do ativo, medindo a facilidade de conversão deste ativo em outro, na composição do portfólio; e $a$ é a taxa de valorização esperada do ativo no final do período (Wray, 2006).

(7) Ver Keynes (1982, p. 161-164).

(8) Para entender os motivos pelos quais os agentes demandam moeda, ver Keynes (1985, p. 124).

(9) O conceito de convenção se refere a um conjunto de regras de representação coletiva. Se existe uma convenção em dada população, que todos os membros desta população compartilham desta convenção, e cada membro da população acredita que todos os outros membros seguirão tal convenção, está convencionada uma situação (ver Erber, 2011). 
Dentre esses estudos claramente influenciados pelo conceito de Keynes destacam-se duas formas de abordagem: a escola dos convencionalistas franceses (Orléan, 1989; Jodelet, 1989; Dupuy et.al., 1989) e um enfoque institucionalista (Hodgson, 1993, 1998, 2006; Dequech, 2003; 2009). Ambas partem da mesma base e, por isso, possuem um desenvolvimento similar. De modo sucinto, a primeira define convenção como um conjunto de regras de representação coletiva para regular as expectativas a priori, decorrente da existência de um problema de coordenação específico devido à complexidade do sistema de mercado (Orléan, 1989); a segunda, a partir do institucionalismo pós-keynesiano, define convenção como uma instância particular de uma regra institucional, construída e compartilhada entre os indivíduos para guiar o estado das expectativas num ambiente de incerteza não-matemática. Diferente das instituições formais, os indivíduos a seguem não apenas porque há uma pressão externa para cumprir ou sanções para quem descumpri-la, mas sim de modo consciente, porque espera-se que os demais agentes estejam em conformidade com a convenção (Dequech, 2003; 2009).

A taxa de juros, portanto, é determinada convencionalmente, pela demanda especulativa de moeda, dada pela preferência pela liquidez. A avaliação do mercado sobre o futuro da taxa de juros resultante da "psicologia das massas", em uma relação entre "altistas" e "baixistas" é que a determina. Não se deve, todavia, afirmar inequivocadamente que um aumento da taxa de diminui o desejo em manter riqueza líquida, fazendo com que alguns "altistas" passem a compor o grupo dos "baixistas", pois "podem surgir muitos percalços entre a taça e os lábios", como por exemplo a “armadilha da liquidez" (Keynes, 1985, p. 123-125).

A taxa de juros sobre o dinheiro possui importância fundamental na determinação do montante de emprego. O empresário determina um nível de demanda efetiva, o qual leva em consideração determinado nível de produção, preços e lucros. Neste instante, o patamar de taxa de juros deve ser tal, de modo a desencorajar a retenção especulativa. No entanto, se a taxa de juros estiver em um nível muito elevado, de modo que não ofereça qualquer incentivo para que o capital empresarial migre da circulação financeira para a industrial, provocará efeitos danosos aos níveis de emprego e produção (Wray, 2006).

Ademais, o empresário necessita de meios de pagamento para efetivar o investimento, isto é, de financiamento. Na maioria das vezes, o acesso aos recursos preexistentes dentro do processo de expansão da renda é dado pelo fluxo de crédito criado pelo sistema financeiro. De acordo com Lavoie (1992), os bancos e as demais instituições financeiras fornecedoras de crédito têm como função primordial a criação de novas unidades monetárias que viabilizem a produção. Segundo De Paula (1999) os bancos fazem suas escolhas de portfólio com base na teoria da preferência pela liquidez da firma bancária. Desta forma, as decisões sobre a composição do portfólio dos bancos comerciais, entre aumentar seu passivo ou tornar-se mais 
líquido, afetam a atividade econômica, ao determinar as condições de liquidez e a capacidade de financiamento do sistema. Esta estrutura de passivo endogenamente determinada contrapõe-se à concepção "clássica" da intermediação financeira com eficiência alocativa dos recursos.

A política monetária (e creditícia) torna-se um instrumento central nesse processo, pois possui a capacidade de promover efeitos duradouros nas relações econômicas reais. O objetivo fundamental da política monetária, de forma coordenada com as demais políticas ${ }^{10}$, é tentar impulsionar a economia para um nível mais próximo ao de pleno emprego, evitando assim as crises de demanda. Sua atuação deve ser permanente, pois a preferência pela liquidez dos agentes e das firmas (incluindo aqui a firma bancária) é bastante instável e a taxa de juros resistente à queda. Em termos práticos, a política monetária deve ser utilizada de modo a fornecer a liquidez do sistema, por intermédio do controle das reservas bancárias (Minsky, 1986; De Paula, 1999). O resultado não seria necessariamente inflacionário, e isto se deve justamente ao fato de a economia quase nunca operar sobre o nível de pleno emprego.

Se por um lado Keynes e os pós-keynesianos defendem a importância dos mercados financeiros para o fornecimento de crédito para o setor produtivo, por outro reconhecem a possibilidade de um predomínio da esfera financeira, à medida que o mercado financeiro se sobrepõe ao produtivo e se torna o lócus das operações especulativas (Mollo, 2015). Na TG, Keynes já utilizava o eufemismo da eutanásia do rentista para alertar sobre o impacto das operações especulativas para o bom funcionamento econômico. Os rentistas correspondem aos detentores do dinheiro, considerado escasso, que exploram esse valor de escassez e se beneficiam com a elevação da taxa de juros. A redução da taxa de juros a um nível que incentive o investimento produtivo poderia promover não apenas a redução do nível de desemprego como também resultar na "eutanásia do rentier" (Keynes, 1982).

Nos estudos que buscam compreender o estágio do capitalismo contemporâneo, a abordagem de Keynes sobre as operações especulativas abriu um campo de pesquisa para o enfoque (pós)keynesiano, sobretudo no que se que se refere aos estudos sobre dominância financeira. Partindo da perspectiva minskyana $^{11}$ dos ciclos endógenos, os trabalhos de Palley (2013) e Tymoigne e Wray (2014) enfatizam que as mudanças na política monetária e na distribuição de renda verificadas desde a década de 1970 alteraram o padrão de acumulação e desenvolvimento das economias capitalistas e tornaram as estruturas financeiras destes países inerentemente instáveis. Em um plano teórico-conceitual, Epstein (2005) apresenta que o termo financeirização pode ser entendido pelo aumento da

(10) “A política monetária [em Keynes] deve ser coordenada com as outras políticas de governo, nem independente, nem subordinada" (Carvalho, 1994, p. 47).

(11) Ver Minsky (1992). 
importância dos interesses financeiros, dos mercados financeiros, dos atores financeiros e instituições financeiras nas operações das economias nacionais e internacionais. A partir disso, a política econômica das principais economias capitalistas, ao invés de servir de instrumento para alavancar os níveis de emprego, está focada em dar sustentação ao regime de valorização financeira.

Nos países em desenvolvimento, como aponta Karwowski e Stockhammer (2016), o processo de financeirização apresenta algumas características diferentes em relação aos países desenvolvidos, tratando-se portanto, de um processo peculiar de financeirização. Dito de outro modo, verifica-se o desenvolvimento de um processo de financeirização com conformações específicas locais. Em boa parte destes países, por exemplo, a despeito da heterogenia entre eles, um processo particular de dominância financeira baseado na renda dos juros tem sido verificado (Becker et.al., 2010; Bonizzi, 2017). A institucionalidade macroeconômica, e especificamente a política monetária, atua de modo diferente, focada na estabilidade de preços, mas que traz como pano de fundo a garantia da atratividade necessária às operações especulativas.

Seja nos países desenvolvidos, seja nos países em desenvolvimento, as decisões de política monetária, sobretudo a decisão da taxa nominal de juros, envolvem conflitos de interesses entre os diversos setores econômicos. Em uma economia monetária de produção, ao mesmo tempo que juros baixos interessam aos setores produtivos, juros mais elevados interessam os setores rentistas e financistas. Em outros termos, as decisões de política monetária não são neutras, não apenas porque podem influenciar a atividade econômica, mas principalmente no sentido de que geram ganhadores e perdedores, tal qual em Modenesi e Modenesi (2012). Pelo fato de serem os detentores do "dinheiro escasso", os rentistas e financistas geralmente estão em vantagem nesta correlação de forças.

O processo de financeirização, no entanto, caracteriza-se por um aumento na participação de empresas não financeiras e famílias nas formas financeiras de riqueza, não se restringindo às alterações do comportamento do sistema financeirobancário. A busca de lucros financeiros de bancos e empresas não financeiras e a modificação da alocação de renda no portfólio das famílias, alteraram as bases do funcionamento de uma economia monetária de produção. Por este motivo, as relações político-econômicas resultantes desta nova dinâmica são complexas e devem ser analisadas de modo mais atento.

\section{0 regime de política monetária e a convenção conservadora da taxa de juros no Brasil}

O Brasil implementou o regime de metas de inflação (doravante RMI) no ano de 1999, seguindo o modelo de política monetária que estava sendo 
recomendado e difundido ${ }^{12}$ ao redor do planeta. Este regime é embasado pela teoria do Novo Consenso Macroeconômico, e caracteriza-se, segundo Bernanke e Mishkin, (1997), por uma política monetária que tem como foco primordial a perseguição de uma inflação baixa e estável por meio de uma meta numérica previamente anunciada (ou uma banda de variação) para a taxa de inflação (medida com base em um índice selecionado), dentro de um intervalo pré-definido. $\mathrm{O}$ principal instrumento à disposição dos policy makers é a taxa de juros.

$\mathrm{Na}$ experiência brasileira, a taxa referencial é a taxa Selic, que é definida pelo Comitê de Política Monetária (Copom), a partir de uma função de reação dada por uma regra de Taylor modificada. A meta inflacionária é anunciada pelo Conselho Monetário Nacional (CMN), sendo que recentemente tem estipulado um patamar de $4,5 \%$ com uma banda de variação de $2 \%$. E o índice de preços selecionado para medir a inflação é o Índice de Preços ao Consumidor Amplo (IPCA/IBGE) optando-se desde o início, na tentativa de dar mais credibilidade ao regime, pelo índice cheio, isto é, aquele que não expurga os elementos voláteis ou os preços administrados do índice de preços (Gomes; Aidar, 2005).

Como mencionado anteriormente, a taxa de juros brasileira é bastante elevada quando comparada à experiência internacional. Alguns trabalhos, como Bresser-Pereira e Gomes (2009), Modenesi et Modenesi (2012) e Campedelli e Lacerda (2014), apontam que a ideia subjacente à concepção do RMI no Brasil, era de que o novo regime pudesse estabelecer condições, a partir da construção da credibilidade, para uma redução do patamar da taxa de juros, além da promoção de reformas estruturais como, por exemplo, o fim da indexação dos preços administrados, o que de fato não foi verificado. É bem verdade que a taxa Selic sofreu uma redução desde a implementação do RMI em 1999, contudo a um nível muito aquém do que se esperava, e o Brasil continuou a praticar taxa de juros reais altíssimas.

A experiência brasileira, portanto, é marcada por uma forte rigidez, sobretudo em função da exorbitância das taxas de juros praticadas, que mesmo com a estabilidade de preços e a adoção de superávits fiscais (por mais de uma década) para conter o déficit público, não foi possível baixá-la a níveis tidos como "normais". A inflação, por outro lado, apesar de se situar dentro da meta intervalar estabelecida desde 2004, tem se mostrado elevada quando comparada a outros países que adotaram o RMI, especialmente em se tratando das excessivas taxas de juros praticadas pela economia brasileira.

(12) O regime de metas passou a ser recomendado pelo FMI para vários países em desenvolvimento após as primeiras experiências bem sucedidas. A despeito de se referir ao mesmo modelo, existe bastante diferença nas experiências práticas de cada país. 
Esta situação de rigidez do RMI tem descoordenado as principais variáveis macroeconômicas. A política monetária vigente e a prática de elevadas taxas de juros afetam negativamente parâmetros como dinamismo econômico (PIB, nível da indústria, montante de emprego, dentre outros), o padrão de renda da população, o montante da dívida pública e a trajetória da taxa de câmbio (Araújo et.al., 2016). O resultado de todo este processo é, em consonância com a análise de Bresser-Pereira e Gomes (2006) e de outros estudos empíricos, um relativo êxito da política monetária brasileira em controlar a inflação, contudo, às custas de elevados custos econômicos.

As causas dessa limitação na política monetária brasileira é campo de vasto estudo entre os economistas heterodoxos. Segundo Carvalho (2009, p.63), a economia brasileira apresenta uma série de peculiaridades que modificam o modo de funcionamento da política monetária no país. O autor destaca a forma como o histórico problema com a inflação impediu a "constituição de uma curva de rendimentos para além do curto prazo", bem como, mesmo após a estabilização monetária, impossibilitou alcançar "uma situação de normalidade financeira". Outra questão refere-se à necessidade de uma elevada taxa de juros de curto prazo para a atração de capital especulativo, dada a dependência dos influxos de capitais deste tipo para o fechamento das contas externas brasileiras, seja no contexto na âncora cambial, seja no contexto pós-adoção do regime de câmbio flutuante.

O trabalho de De Paula e Saraiva (2015), analisando o caso brasileiro inserido em uma lógica de país emergente, elenca alguns fatores de rigidez, tais como as dificuldades relativas à previsão da inflação, o elevado nível de repasse cambial sobre os preços domésticos, os resquícios da indexação ${ }^{13}$ de preços, o curto período de tempo para o cumprimento da meta e a elevada amplitude das obrigações em moedas estrangeiras. Sobre o horizonte temporal, em singular, os autores avaliam que o Brasil é um dos poucos países - mesmo em relação aos países emergentes - a apresentar uma meta anual. Neste contexto, qualquer elevação verificada no nível geral de preços, mesmo aquela não relacionada a pressões de demanda, deve ser respondida de maneira imediata com a elevação da taxa básica de juros pelo Bacen (De Paula; Saraiva, 2015).

Outros trabalhos recentes têm dado maior ênfase à baixa sensibilidade do nível geral de preços do Brasil em relação à atividade econômica e à taxa de juros enquanto um fator determinante para a rigidez. Em linhas gerais, a política monetária tem reduzido impacto deflacionário, pois, como a taxa de inflação responde de modo pouco sensível à variação na taxa Selic, uma "dosagem" de taxa de juros cada vez maior se faz necessária para que a inflação convirja para meta. (Modenesi;

(13) Para compreender melhor a relação entre o processo de indexação de preços e taxa de inflação e taxa de juros no Brasil, ver Oreiro e De Paula (2010) e De Carvalho (2014). 
Modenesi, 2008; Oreiro et al., 2012). Segundo Modenesi e Modenesi (2008), a combinação de uma inflação resistente (apesar de dentro da meta) e taxas de juros extremamente elevadas é um forte indício de que há alguma falha na transmissão da política monetária. Além disso, ainda segundo os autores, o efeito da taxa de juros sobre o nível de atividade econômica é claramente negativo, isto é, o aumento dos juros desacelera a economia e aumenta o desemprego.

A baixa sensibilidade da taxa de inflação em relação à taxa de juros é dada a partir de uma combinação de fatores. Arestis et al. (2009) aponta que a inflação no Brasil tem sido basicamente de custos, relacionada a choques de oferta e a uma inércia parcial causada pela indexação de preços administrados. Em direção similar, Mendonça (2007) enfatiza o elevado peso dos preços administrados na composição do índice do IPCA, que na verdade deveriam considerar apenas os preços livres, pois aqueles são insensíveis em relação à taxa de juros. Ademais, Oreiro et al. (2012) sustenta que a indexação diária dos títulos públicos, dada pela cláusula do preço de recompra, contribui para eliminar o efeito riqueza da política monetária, tornando-a ineficiente. Destaca-se ainda que, em um ambiente de elevadas taxas de juros, os agentes também tendem a ficar menos sensíveis a pequenas variações nos juros, necessitando de altas variações e, consequentemente, taxas de juros de curto prazo cada vez mais elevadas para promover choques contracionistas na atividade econômica.

Existe ainda uma explicação com base na economia política, na qual as decisões de política monetária, assim como as demais políticas econômicas, não são neutras, no sentido de que as decisões do governo geram ganhadores e perdedores (Modenesi; Modenesi, 2012). Assim, a condução da política monetária interessa aos diversos setores econômicos, correspondendo a uma verdadeira guerra entre "blocos de poder" 14 , com defesas de posições entre os diversos setores interessados ${ }^{15}$. Por serem os detentores do dinheiro ${ }^{16}$, os setores rentistas e financistas estão em vantagem nesta correlação de forças e, a partir disto, tem se consolidado uma convenção ${ }^{17}$ pró-conservadora na determinação da taxa de juros (Modenesi, 2008; Erber, 2011).

(14) Termo marxista utilizado para designar os conflitos de interesses entre as classes do bloco dominante. Para mais informações, ver Teixeira e Pinto (2012).

(15) Grande parte da heterodoxia econômica considera que existem componentes de disputa política que influenciam na tomada de decisão das autoridades monetárias, e que são inerentes à própria lógica de um sistema “capitalista democrático". Esta disputa política tem a taxa de juros como uma de suas representações mais categóricas.

(16) Em face disto, o sistema financeiro, representação convincente do setor rentista, pode "capturar" a autoridade monetária, pois são estes que, tal qual em Keynes, determinam (em última instância) a demanda agregada mediante as operações de crédito (liquidez) (ver Terra, 2014, p. 11).

(17) Para Erber (2011, p. 34): “a força de uma convenção é proporcional ao tamanho de P (população) e ao poder político e econômico dos seus membros. Tal força proporciona benefícios aos que aderem à convenção e sanciona os que dela se afastam Em consequência, $\mathbf{P}$ contem não apenas 'crentes', como 'oportunistas' movidos apenas por razões utilitárias" (grifo do autor). 
Um dos primeiros trabalhos a sugerir a existência de uma convenção na formação dos juros no Brasil, foi o de Bresser-Pereira e Nakano (2002). Segundo os autores, a manutenção de um nível excessivo da taxa de juros por um longo período de tempo gerou o "medo de uma redução", e tal medo formou uma convenção em torno da manutenção de juros elevados, que funciona como uma espécie de armadilha (Bresser-Pereira; Nakano, 2002, p. 169). Trabalhos posteriores buscaram algumas evidências da formação de uma convenção na taxa de juros brasileira. Nakano (2006), analisando as relações entre as variáveis que formam a função de reação, sustenta que o Bacen adota uma regra de suavização que impede bruscas alterações, mesmo quando as condições econômicas são favoráveis para tal. Em termos práticos, o resultado é que estabeleceu-se um piso elevado para a taxa de juros real, que independe de pressões inflacionárias ou do nível de atividade (Nakano, 2006). Na mesma direção, Modenesi (2008) apresenta o argumento que a regra de Taylor brasileira apresenta lentidão no movimento da taxa de juros, o que indica um excesso de gradualismo e conservadorismo na operacionalidade da política monetária brasileira. Além disso, o autor sugere que a taxa de juros brasileira tem um elevado "nível de equilíbrio". Estas observâncias reforçam a ideia de uma convenção pró-conservadorismo na condução da política monetária brasileira (Modenesi, 2008).

Os juros, em particular, representam grande parte do lucro ou da renda do capital especulativo, que abrange não apenas os bancos comerciais, instituições de créditos, corretoras, instituições fundos de pensão, etc., mas também os detentores de grandes quantidades de dinheiro para fins rentistas. Combinado ao fato de se beneficiarem de uma inflação baixa, pois desta forma os rendimentos reais não estariam comprometidos, estes setores pressionam as autoridades para manutenção de elevadas taxas de juros nominais de modo a atender seus interesses.

Os mecanismos de atuação dos setores rentistas e financistas na manutenção de taxas de juros elevadas parecem ser triviais, mas podem ser analisados mais de perto. A começar pela dinâmica do capital financeiro nacional e internacional, estes se abastecem das altas taxas de juros que remuneram a dívida interna e externa, em grande parte nas mãos do próprio grande capital financeiro internacional. Por isso, difundem a ideologia ortodoxa de preocupação central com a inflação (Teixeira; Pinto, 2012). Um segundo mecanismo refere-se aos instrumentos utilizados pelos formuladores de política monetária do Bacen para a captação das expectativas inflacionárias do público. Participam da reunião do Copom diversos representantes de departamentos que expressam o sentimento de mercado. Algumas críticas questionam a representatividade destes setores, pois consideram que a fixação da taxa de juros pelo Copom é feita com base em expectativas inflacionárias de agentes que não tem efetivo poder formador de preços, além de refletir em grande medida a percepção (e consequentemente os interesses) do mercado financeiro (Oreiro; 
Passos, 2005). Existem também instrumentos mais implícitos ou obscuros, como aponta Erber (2011), no qual os setores rentistas e financistas difundem a convenção conservadora, como por exemplo, a lógica do retorno do financiamento de campanhas eleitorais, as relações com os membros do congresso e os aparelhos de controle da grande mídia.

Em grande medida, portanto, a convenção existente é fruto do interesse hegemônico de alguns grupos específicos interessados no pagamento de juros elevados (Seabra; Dequech, 2013). Por possuírem grande poder político e muita riqueza econômica, os interesses destes setores interessados prevalecem e estes conseguem convencer a população de que a elevada taxa de juros representa um "bem comum" (Erber, 2011, p. 35). Ademais, o sistema bancário nacional, representante de boa parte do setor financista, além de detentor do dinheiro escasso, é bastante oligopolizado, o que o deixa em uma posição ainda mais privilegiada no processo de acumulação e distribuição da riqueza.

A convenção estruturada sobre as altas taxas de juros tem como argumentação (para convencer a ideia de "bem comum"), um conjunto de conhecimentos codificados e tácitos que formam o "núcleo duro" da convenção ${ }^{18}$ (ver Erber, 2011). Os conhecimentos codificados são aqueles dos acadêmicos e dos analistas do mercado financeiro - que determinam o investment grade, por exemplo -, dotados de prestígio e embasados pelo pensamento dominante baseado no Novo Consenso. No plano dos conhecimentos tácitos, pode-se citar alguns fatos históricos ocorridos nas décadas de 1980, 1990, como por exemplo, o temor da volta da inflação, a lembrança da moratória de 1987, a crise cambial de 1999, dentre outros, que moldaram as percepções dos agentes econômicos.

Seabra e Dequech (2013) apontam que para consolidar a convenção da taxa de juros, tal convenção deve ser incorporada pelo órgão responsável na sua determinação. Também para Erber (2011), o Bacen é uma peça fundamental para a coalizão convencional em favor daqueles que se beneficiam dos juros elevados. No entanto, não é somente pela influência política e econômica destes últimos que o Bacen se curva diante da convenção. Sob o RMI, o Bacen incorpora a convenção movido por interesses próprios. $\mathrm{O}$ argumento básico é de que a manutenção de uma taxa Selic elevada torna menos sinuoso o caminho para o cumprimento da meta, aumentando sua reputação e credibilidade (Erber, 2011; Seabra; Dequech, 2013).

Portanto, a conciliação de interesses específicos entre o setor interessado no pagamento de juros e o órgão responsável pelo cumprimento da meta tem formado o "núcleo duro" em torno desta convenção que tem ditado a condução de política

(18) Esta mesma ideia de convenção pode ser aplicada ao problema da armadilha da dívida pública brasileira, pois a preferência pela liquidez e, consequentemente, a taxa de juros, dependem da sustentabilidade da dívida pública e da capacidade do governo em honrar seus compromissos. 
monetária após a introdução do RMI. A taxa de juros passa a ser determinada de forma autorrealizável, isto é, tende a flutuar em torno de um patamar que os agentes consideram normal.

\section{A gestão de política monetária no governo Dilma: condicionantes gerais e "pontos sensíveis"}

A discussão sobre a trajetória da taxa de juros durante o primeiro governo Dilma deve ser feita à luz das armadilhas estruturais da política macroeconômica brasileira que impelem na prática de elevadas taxas de juros e da tentativa de ruptura destes problemas estruturais pelo governo. Além disso, conforme mencionado, a redução histórica da taxa Selic continha também um objetivo mais de curto prazo, qual seja, o de promover estímulos à demanda doméstica que dava sinais de desaceleração neste momento.

À política escolhida foi dado o nome de Nova Matriz Econômica. Esta denominação, presente inclusive na retórica oficial do governo, correspondia a um novo modelo de política macroeconômica, que significava na prática uma remodelação do tripé. O "novo tripé” centrava-se em taxas de juros mais baixas, uma taxa de câmbio competitiva e uma política fiscal "amigável" ao investimento, além da perspectiva de um PIB da ordem de 3,5\% (Mantega, 2012). Deve-se ressaltar que esta nova política não tinha por intuito substituir o tripé ortodoxo. O governo vislumbrava a possibilidade de ajustar os parâmetros macroeconômicos considerados imperfeitos a partir da pauta existente. De fato tentou-se o tempo todo compatibilizar as novas diretrizes com o regime macroeconômico vigente.

Ao assumir a presidência em janeiro de 2011, Dilma se deparou com um cenário controverso. Por um lado, as perspectivas dos analistas para o quadro econômico brasileiro eram bastante positivas. Pires e Galhardo (2015) apontam alguns motivos para tal sentimento, citando a taxa de crescimento do produto experimentada no ano anterior - da ordem de 7,5\% em um momento que a economia mundial estava praticamente estagnada - e a postura da nova presidente eleita, historicamente identificada com o discurso desenvolvimentista. Por outro lado, havia uma instabilidade econômica que incomodava os policy makers brasileiros. De fato, a inflação vinha se mostrando crescente desde meados de 2010 , fechando o ano em $5,9 \%$ e alcançando o teto da meta no acumulado em março de 2011. A herança do final do governo Lula, marcado por uma descoordenação das principais variáveis macroeconômicas resultante das políticas de enfrentamento da crise internacional, impactou dentre outros problemas, em uma pressão inflacionária conjuntural ${ }^{19}$.

(19) Conforme publicado pelo relatório do Banco Central de 2011, contribuíram para o quadro inflacionário fatores conjunturais internos como uma inflação de demanda provocada pelo crescimento elevado do ano anterior, ao reajuste de algumas tarifas públicas, e fatores externos como a elevação dos preços dos serviços, das commodities e dos produtos in natura. 
Dessa forma, considerou-se crucial conter as pressões inflacionárias do início do governo para lançar mão de qualquer tentativa de mudança. Com efeito, o primeiro semestre foi marcado por políticas fiscais e monetárias restritivas. Em cinco reuniões do Copom, durante um intervalo de oito meses, a taxa nominal de juros se elevou em 1,25\% ao ano, atingindo o ponto máximo de $12,50 \%$ em junho, patamar este que foi mantido até o final do mês de agosto. O Bacen optou claramente por uma proposta gradual de combate à inflação, com elevações cautelosas da taxa básica de juros nesse período.

Concomitantemente ao aumento da taxa de juros, o governo optou, também já na primeira reunião, pela manutenção das medidas macroprudenciais de controle seletivo de crédito e de câmbio, iniciadas no final do governo Lula. Estas medidas fazem parte da diversificação do mix de instrumentos de política monetária ${ }^{20}$ e são fundamentais para o objetivo de não-apreciação cambial. Tais medidas requeriam uma maior coordenação da política monetária com as demais políticas econômicas, que pôde ser verificada pela atuação conjunta do Bacen com o Ministério da Fazenda nesse momento (Cagnin, et al., 2013).

A partir do segundo semestre, dava-se início a um subperíodo que é o ponto central da análise da inflexão da política monetária do primeiro governo Dilma. Este é marcado por uma queda contínua e acentuada da taxa básica de juros, tendo esta chegado ao piso histórico de 7,25\% ao ano em outubro de 2012, e permanecido nesse patamar por durante seis meses. $O$ mercado foi surpreendido pela decisão de corte da Selic em 0,5 p.p. em 31 de agosto de 2011. A explicação da decisão pelo Copom foi de que a inflação do primeiro semestre seria proveniente dos choques de oferta, e que os riscos derivados da persistência do descompasso entre as taxas de crescimento da oferta e da demanda passavam a ocorrer em intensidade decrescente. Deve-se considerar também, em consonância com Cagnin et al. (2013), que a degradação no cenário externo resultante dos desdobramentos da crise da Zona do Euro contribuía para os efeitos deflacionários nos principais países do mundo.

As três reuniões posteriores do Copom em 2011 optaram pela continuidade do corte da taxa Selic, fechando o ano no patamar de 10,90\% ao ano. Após um total de dez quedas consecutivas, a taxa básica de juros chegou a 7,25\% em outubro de 2012, refletindo o nível mais baixo desde a criação do Copom em 1996. Cabe salientar que os cortes na Selic não foram tão graduais como havia sido a elevação no primeiro semestre de 2011. Este patamar foi mantido até março de 2013, sempre sob o argumento de que havia um cenário prospectivo favorável para a inflação, causado basicamente pelo fraco desempenho de atividade doméstico e de baixo dinamismo da economia mundial.

(20) Estas medidas têm por objetivo tornar a política monetária mais flexível. Para mais, ver Cagnin et al. (2014). 
As medidas de afrouxamento da taxa de juros foram complementadas por outras medidas das demais autoridades da área econômica. No final de 2011, entre os meses de novembro e dezembro, o CMN e o Bacen, a fim de tentar estimular a demanda, decidiram por reverter parte das medidas restritivas ao crédito de caráter macroprudencial $^{21}$.

O governo federal ainda iniciou nesse período uma medida que tem sido bastante questionada pelos economistas ortodoxos. Trata-se da ampliação do papel dos bancos públicos, sobretudo do BNDES, da Caixa Econômica Federal e do Banco do Brasil, na fomentação do investimento produtivo. A atuação ampliada dos bancos públicos deu-se no sentido de impor uma concorrência aos bancos comerciais, forçando-os a reduzirem os spreads de suas operações de empréstimo, fazendo com que a política de juros obtenha o resultado desejado (Paulani, 2015). Ao longo de 2012, percebeu-se uma tentativa dos bancos de garantirem seus lucros mediante o aumento das tarifas bancárias. O governo novamente, em outubro, lançou mão dos bancos públicos no intuito de reduzir as tarifas visando que os bancos comerciais seguissem a mesma rota (Dieese, 2013).

A política de redução de juros provocava uma melhora nas contas públicas brasileiras, por meio da redução da dívida pública nominal, altamente indexada. Este quadro viabilizava o aumento das despesas públicas que estavam associadas ao resultado primário, como as políticas de desonerações as políticas de concessão de crédito público, além de elevar a capacidade de endividamento dos estados e municípios e, consequentemente, o potencial de investimentos em infraestrutura. A redução dos juros contribuía também para a desvalorização cambial que estava na pauta dos objetivos do governo ${ }^{22}$.

O período entre abril de 2013 e dezembro de 2014 foi marcado por uma retomada gradual do conservadorismo na política econômica (sobretudo no que se refere à taxa de juros), turbulência política e uma piora geral nos resultados macroeconômicos. Foi cada vez mais suscitado, então, a discussão sobre um eventual fracasso do ensaio desenvolvimentista do governo Dilma. O panorama econômico brasileiro no momento em que o governo opta pela reversão da política de juros não era nada animador. O mercado apontava perspectivas pessimistas para o crescimento do PIB para o ano de 2013, após dois resultados ruins para 2011 e 2012. A produção industrial e o consumo doméstico pareciam estagnados. A inflação

(21) A Circular n. 3563 revogou a exigência de capital adicional para as operações de empréstimos ao consumo com prazo máximo de 60 meses. A Circular n. 3512, desistiu de elevar o percentual mínimo de pagamento das faturas de cartão de crédito de $15 \%$ para 20\%, que havia sido determinado em junho de 2011 (Cagnin et al., 2013).

(22) A desvalorização real foi da ordem de $20 \%$ considerando os dois primeiros anos de governo. Este cenário permitiu que se adotasse uma política mais moderada no que concerne às intervenções no mercado de câmbio. 
que se manteve no teto da meta em 2011 e 2012 dava sinais de piora, o que configurava um quadro desconfortável de inflação persistente e estagnação econômica. Além disso, a crise internacional se aprofundava, com a deterioração da situação econômica de países da Zona do Euro, sobretudo dos chamados PIIGS e uma constante desaceleração da economia global.

O Copom, na reunião de 17 de abril de 2013, decidiu pelo aumento de 0,25 p.p. da taxa Selic, passando para 7,50\% ao ano. A cautela inicial no combate à inflação advinha da incerteza econômica que pairava naquele momento. A explicação do Comitê pela opção de elevação da taxa de juros foi que a inflação se mostrou resistente, não cedendo mesmo após iniciada a reversão. O fato que deixou os analistas surpresos foi a decisão tomada pelo Comitê na reunião seguinte, de 29 de maio. Isso porque decidiu por elevar a taxa Selic em 0,5 p.p., abandonando a política de ajuste gradual no momento em que a crise internacional se aprofundava. $\mathrm{O}$ argumento para tal decisão era o fato de ter havido uma piora nas expectativas dos agentes de mercado acerca da inflação. Após sucessivas reuniões e seguidas elevações dos juros, a taxa Selic fechou o ano de 2013 em um patamar de $10 \%$ ao ano. O mesmo ocorreu durante todo o ano de 2014, atingindo $11,75 \%$ em dezembro, ou seja, retornando para patamares superiores àqueles de quando Dilma assumiu o governo.

A política fiscal não acompanhou este movimento dos juros, mesmo com o recrudescimento inflacionário. $\mathrm{O}$ intuito do governo era tentar manter um eixo da política anticíclica em um momento em que as projeções eram pouco animadoras para o ano de 2013 (Pires; Galhardo, 2015). Na tentativa de não apresentar um pífio resultado de crescimento do PIB no último ano que antecede o ano eleitoral, foi mantida (e aprofundada) a política de desonerações fiscais ${ }^{23}$. O governo, porém, não conseguiu continuar a política de capitalização dos bancos públicos a partir do segundo semestre de 2013, devido à preocupação com o resultado primário. Tal preocupação advinha do fraco desempenho do nível de atividade que refletia em uma diminuição da receita tributária. Este quadro de retração do crédito público e piora no resultado fiscal se arrastou por todo o ano de 2014.

Pelo lado cambial, a piora do cenário econômico internacional trazia consigo uma degradação dos termos de troca e, consequentemente, uma apreciação da taxa de câmbio real. A desvalorização de $20 \%$ do Real em relação ao Dólar americano durante estes dois anos, por outro lado, não foi suficiente para alavancar o crescimento industrial, restando apenas pressões inflacionárias e redução da massa salarial real (Barbosa-Filho, 2015).

(23) O superávit primário para 2013 foi inferior aos de 2011 e 2012 não apenas em função das desonerações, mas também dos gastos previstos com os investimentos públicos do PAC e das obras para a Copa do Mundo. 


\section{A economia política da política monetária do Governo Dilma: o alarmismo dos setores que se beneficiam da renda dos juros}

Em uma perspectiva a posteriori, a redução acentuada da taxa de juros não foi capaz de promover um aumento do investimento produtivo privado e, por consequência, impulsionar o crescimento econômico. Tampouco foi capaz de atingir seu objetivo no plano estrutural, pois, a reversão da trajetória da taxa de juros iniciada em abril de 2013 pode ser considerada como o marco que expressa o malogro da tentativa do governo.

As razões para o fraco desempenho do investimento produtivo são motivo de um intenso debate entre os economistas, que segue longe de ser consensual. Em termos keynesianos, a política de juros (no bojo das demais políticas econômicas) não foi capaz de incentivar a migração do capital financeiro para o capital produtivo. Para Barbosa-Filho (2015), os empresários não se sentiram tentados a investir por conta de uma combinação de fatores, dentre os quais destacam-se uma forte incerteza macroeconômica e uma piora na rentabilidade esperada dos investimentos de longo prazo. Segundo o autor, rentabilidade esta que já vinha caindo desde a crise internacional e foi agravada por um quadro de incerteza econômica e política que permaneceu durante todo o governo Dilma.

As incertezas que rondavam a economia brasileira são resultantes de fatores internos e externos. No âmbito interno, destaca-se os maus resultados macroeconômicos ${ }^{24}$, sobretudo o baixo dinamismo do investimento, o pífio crescimento do PIB, a desaceleração da oferta de crédito livre, a deterioração das contas externas e uma inflação persistente. Ademais, o agravamento da crise política na medida em que se aproximava as eleições de 2014, contribuía para o aumento da crise de confiança e de expectativas. No âmbito externo, as dúvidas em torno dos indícios de recuperação da crise financeira internacional foram findadas pelos desdobramentos da crise financeira-fiscal dos países da zona do Euro a partir de 2011 e de uma gradual desaceleração da China - um dos países mais importantes nas relações comerciais com o Brasil no período recente - que pode ser vista a partir de meados de 2012 (Biancarelli, 2014; Barbosa-Filho, 2015).

A falta de sinalização dos objetivos e dos rumos futuros da política macroeconômica, na medida em que tornava obscuro o ambiente para a tomada de decisão dos agentes empresariais, elevava a preferência pela manutenção de riqueza líquida. Inseridos na lógica da financeirização e suas características anômalas para o caso brasileiro ${ }^{25}$, os detentores do dinheiro preferem manter estes ativos na

(24) As causas dos maus resultados macroeconômicos também são diversas, dadas tanto por problemas de ordem política quanto econômica. Algumas delas podem ser vistas em Biancarelli (2014).

(25) Para Bruno (2011), predomina-se no Brasil, desde a abertura financeira, um processo de financeirização em que os ganhos se derivam principalmente da renda dos juros, impulsionada pelo Estado e que tem como eixo central a dívida pública. 
circulação financeira, a qual oferece, além da liquidez imediata, baixo risco e elevada rentabilidade ${ }^{26}$.

Sem a pretensão de negligenciar todos os fatores expostos acima, procurarse-á explorar aqui uma outra explicação, calcada em uma relação de causalidade com o poderio econômico e político dos setores rentistas e financistas, que viram seus interesses prejudicados pela política monetária adotada, e se uniram em desfavor desta última.

Um primeiro desconforto causado logo no primeiro mês do governo Dilma foi a oficialização da troca de presidente no Banco Central em janeiro de 2011, substituindo Henrique Meirelles, pessoa de confiança do setor financeiro, por Alexandre Tombini, funcionário de carreira do Bacen. Contudo, tão logo foram mantidas as linhas gerais da política monetária nos seis primeiros meses, o novo presidente do Bacen adquiriu a confiança necessária do mercado para implementar as mudanças no segundo momento.

A redução da taxa básica de juros no mês de agosto causou certa surpresa aos setores rentistas e financistas. Segundo Nakano (2011), percebeu-se um relativo protesto de parte da ortodoxia mais liberal, que previa pressões inflacionárias com a redução de 0,5 p.p. da Selic e temia que a tecnicidade do Bacen fosse abandonada em prol das decisões políticas. No entanto, passado o frisson inicial, as opiniões dos representantes dos setores financistas passaram a transmitir otimismo na grande mídia e na mídia especializada, pois viam o nascimento de uma "nova ordem financeira" nesta tendência de redução dos juros e vislumbravam possibilidades de aumento de operações de crédito, mais do que compensando a perda de rentabilidade pela redução da Selic.

É verdade também que a redução da taxa nominal de juros já vinha ocorrendo ao longo da última década, sem que isso causasse (ao menos explicitamente) desconforto entre os setores interessados. Entretanto, deve-se considerar algumas diferenças entre os governos de Lula e Dilma. Primeiramente, a queda relativamente vagarosa da taxa Selic ao longo do governo Lula, somado à melhora no quadro inflacionário, resultava em taxas reais de juros ainda bastante elevadas. Até mesmo no auge da crise financeira internacional, quando adotadas as medidas de resposta à crise em 2009, a taxa de juros real variou em torno de um patamar $4 \%$, enquanto a maioria dos países desenvolvidos operavam com taxas de juros reais nulas ou negativas. Já no governo Dilma, a queda da taxa básica de juros, além de ter sido muito mais drástica, foi acompanhada de uma inflação resistente, cujo patamar quase atingia o teto da meta e que se manteve presente mesmo após

(26) Lacerda (2013) argumenta que as altas taxas de juros oferecidas pelos títulos públicos brasileiros de curto prazo sempre feriram a lógica do trinômio rentabilidade, risco e liquidez, geralmente inversamente proporcionais 
iniciada a política de reversão. Este quadro de inflação persistente e diminuição da taxa de juros gerava uma diminuição dos rendimentos reais dos setores rentistas e financistas ${ }^{27}$.

Em segundo lugar, os resultados macroeconômicos favoráveis durante o governo Lula, sobretudo no que diz respeito ao crescimento econômico, baixo desemprego, melhora nos índices de distribuição de renda, aumento nas exportações, redução da vulnerabilidade externa, a obtenção do investment grade em 2008, etc., colocavam o Brasil na situação de um país de oportunidades para o capital estrangeiro. Estes bons resultados davam menor abertura de organização ao setor rentista/financista contra as políticas adotadas. Os mesmos resultados não foram verificados durante o primeiro governo Dilma. De um lado, a taxa de desemprego caiu e a melhora nos índices de pobreza e distribuição de renda continuou (BarbosaFilho, 2015). Do lado negativo, porém, destaca-se a baixa taxa média de crescimento de 2,2\% ao ano entre 2011 e 2014 - sendo 1,6\% ao ano se o recorte escolhido for entre 2012 e 2014 - e a já citada inflação, que permaneceu sempre próximo no teto da meta, com uma inflação média de 6,1\% entre 2011 e 2014.

Além disso, o governo Dilma impôs uma forte concorrência dos bancos públicos no sentido de forçar os bancos comerciais a reduzirem os spreads bancários e, por consequência, reduzir as demais taxas de juros de mercado. O resultado desta política para os bancos comerciais é uma ameaça ao volume e à rentabilidade das operações de empréstimo, mesmo que esta ainda se encontrasse em patamares elevados ${ }^{28}$. O mesmo pode ser verificado ao final do segundo governo Lula, em razão das medidas anticíclicas em 2009, porém de modo bem mais comedido. O intuito de Lula ao lançar mão das linhas de financiamento por parte dos bancos públicos era apenas evitar o empoçamento das operações de crédito resultante das posturas defensivas adotadas pelos bancos comerciais em períodos de incerteza.

Estes aspectos em conjunto, somados à falta de habilidade políticoparlamentar da presidente e a outros problemas de ordem política - tais como, os escândalos de corrupção na Petrobrás e a condenação dos envolvidos no julgamento do mensalão - levaram os setores de oposição, dentre eles, os setores rentistas e financistas, a estruturar um "julgamento violentamente negativo do governo" a partir de 2013, em conformidade com Bresser-Pereira (2015, p.36). A ruptura foi se tornando cada vez mais latente a partir das manifestações de junho de $2013^{29}$ e no

(27) Vale dizer que a redução dos lucros do setor financista não se deu apenas por meio de uma diminuição dos rendimentos reais das operações de empréstimo, mas também, em grande medida, pela redução dos ganhos provenientes de aplicações indexadas à Selic, sobretudo operações em títulos mobiliários (Dieese, 2013).

(28) A demonstração de resultados dos principais bancos comerciais privados do Brasil - Itaú, Bradesco e Santander -, comprova os lucros exorbitantes auferidos por estas instituições nos anos de 2012, 2013 e 2014.

(29) As manifestações populares de junho de 2013 tinham uma conotação apolítica e apartidária, não sendo propriamente e unicamente contra a presidente da república. Entretanto, foi muito bem aproveitada pelos setores insatisfeitos com a condução macroeconômica do governo Dilma. 
período pré-eleitoral em 2014, mesmo após a retomada pró-conservadora da política monetária em abril de 2013.

Para os setores rentistas e financistas, as políticas econômicas adotadas a partir de 2011, em especial a política de redução da taxa de juros, feriram a coalizão em torno da lógica da convenção existente desde a adoção do Plano Real e institucionalizada pelo RMI, a partir de 1999. Em outras palavras, tais políticas representaram uma "quebra de protocolo", assim como em Nakano (2011), das diretrizes impostas pelo RMI. Ao perceberem este movimento, os agentes destes setores se organizaram e usaram seu poder e sua influência no modelo econômico e institucional vigente para influenciar a condução da política macroeconômica em favor da manutenção do status quo ${ }^{30}$.

A atuação destes setores se deu por meio do medo permanente do retorno da inflação, de modo que "plantam inflação para colher juros". Este movimento pode ser visualizado a partir das publicações semanais do boletim Fócus ${ }^{31}$, que a partir de 2013 passaram a expressar uma percepção cada vez mais negativa em relação ao quadro inflacionário. Além disso, iniciou-se um incisivo discurso antiintervencionista, que passou a ser endossado por acadêmicos, analistas de mercado e comentaristas econômicos, associando de maneira oportunista o fracasso dos resultados macroeconômicos do governo Dilma ao excesso de intervenção na economia. De acordo com Singer (2013, p.13), essa ofensiva conseguiu não somente pressionar o governo a recuar e "suspender o ensaio desenvolvimentista", como também dividiu a "coalizão produtivista" 32 , fazendo migrar o capital produtivo para a órbita rentista, fortalecendo ainda mais esta última.

O discurso contra o intervencionismo recaía, espontaneamente, sobre a política monetária, pois considerava que houve uma tentativa "forçosa" e "deliberada" de reduzir a taxa de juros abaixo do seu nível "natural" ou "de equilíbrio", compatível com o nível de desemprego não inflacionário. O resultado final seria, segundo a cartilha ortodoxa, um baixo nível de desemprego às custas de uma inflação elevada de curto prazo e um baixo crescimento econômico no longo prazo. Esta narrativa ganha força quando analisamos a política monetária no bojo das demais políticas econômicas, seus objetivos em conjunto e seus resultados. A questão sobre ter sido uma decisão política e uniliteral do Planalto ou não, estar prevista na modelagem ou não ${ }^{33}$, ou ser “forçosa", é complexa e requer análises mais aprofundadas. $\mathrm{O}$ que o argumento apresentado aqui sugere é que o que estes setores

(30) Em alusão ao termo empregado em Erber (2011).

(31) Boletim realizado pelo Grupo de Relacionamentos com Investidores e Estudos Especiais (Gerin) do Bacen.

(32) Ver Singer (2015)

(33) O modelo DSGE, base da política monetária do RMI, prevê variações para baixo no patamar da taxa de juros do sistema, em função de variações no gap do produto ou da inflação. 
bradavam ser o nível "natural" seria na verdade o seu nível "convencionalmente aceito".

Percebe-se, sobremaneira, a formação de um processo retroalimentado, uma espécie de círculo vicioso de curto prazo na política monetária e na economia brasileira a partir de 2012/2013, no qual os problemas econômicos e políticos podem ser explicados a partir da atuação dos setores interessados na manutenção da convenção, ao mesmo tempo em que o agravamento da crise política e econômica fornece os elementos que dão maior capacidade de organização e atuação a estes setores em prol de seus interesses. Apesar de a ruptura dos setores interessados na manutenção da convenção tratar-se de um momento específico da economia brasileira recente, não significa que não possa se tornar o modus operandi destes setores, inviabilizando de maneira sistemática qualquer tentativa de redução das taxas de juros no Brasil.

\section{Considerações finais}

De modo geral, o presente artigo insere-se nas análises críticas a respeito dos rumos que a economia brasileira vem tomando nas últimas duas décadas. A ideiachave é que modelo macroeconômico do "tripé", ao subordinar as demais políticas econômicas ao regime de metas de inflação e, por conseguinte, à estabilidade de preços, tem sido um instrumento institucional macroeconômico de fundamental importância para os setores rentistas e financistas, no sentido de consolidar o pensamento liberalizante no Brasil, formando um núcleo cada vez mais compacto em torno da manutenção do regime atual.

Por questões pragmáticas, a crítica deste trabalho centrou-se especificamente nas elevadas taxas de juros praticadas pela economia brasileira. $\mathrm{O}$ governo Dilma foi escolhido para a análise, pois verifica-se uma tentativa de romper com alguns limites estruturais da política macroeconômica, dentre eles, a convenção pró-conservadorismo existente na fixação da taxa de juros. A redução da taxa Selic, iniciada em agosto de 2011, não acompanhada de uma queda na inflação, conduziu a taxa real de juros a níveis extremamente reduzidos para os padrões brasileiros, ao menos no recorte histórico pós-Plano Real. A reversão abrupta da trajetória de redução da taxa básica de juros a partir de abril de 2013, retornando a taxa Selic para o patamar de $11,75 \%$ ao ano em dezembro de 2014 , pode ser considerada uma clara demonstração das dificuldades impostas pela economia política em se promover qualquer tipo de alteração da institucionalidade macroeconômica que está posta.

Neste contexto, pôde-se, sem a pretensão de tomar qualquer posição definitiva, trazer à tona algumas questões referentes a este momento peculiar da economia brasileira no período recente. Em primeiro lugar, a redução da taxa de juros resulta diretamente em uma perda de rentabilidade real das operações 
financeiras. Dadas as dificuldades vividas pela economia brasileira nesse período, a redução dos juros também não foi capaz de gerar um efeito compensatório de elevação do montante de operações financeiras. Além disso, para o setor financeirobancário, a simultânea ação dos bancos públicos nas linhas de crédito impunha uma proposital concorrência aos bancos comerciais e demais instituições de crédito, de modo a limitar os ganhos efetivos devido à redução das tarifas e dos spreads cobrados por tais operações. Em face disto, os setores rentistas e financistas sentiram que as políticas adotadas violavam a lógica da convenção em torno de um patamar da taxa de juros real aceito. Com efeito, estes setores, a fim de salvaguardar seus próprios interesses, passaram a se posicionar veementemente contra as políticas adotadas pelo governo.

Cabe observar que a redução dos juros per si não significava uma alteração no modelo de política monetária, cujo corpo teórico contempla reduções na taxa de juros de acordo com o nível de atividade. A dificuldade reside em tentar compatibilizar duas visões ontológicas distintas, isto é, discutir uma tentativa desenvolvimentista de ruptura de armadilhas estruturais imerso na pauta ortodoxa, na qual as políticas monetária, fiscal e cambial estão atreladas aos objetivos do RMI. Esta situação torna qualquer tentativa de mudança na situação vigente uma "presa fácil" a ser combatida pelos setores interessados na manutenção da convenção.

Como resultado, verificou-se o agravamento da crise política e econômica a partir de 2013. O cenário de incerteza da economia internacional tornou o quadro mais obscuro. A baixa taxa média de crescimento do PIB e um quadro de inflação persistente durante o quadriênio 2011-2014 e os aclaramentos de alguns escândalos de corrupção forneceram a substância que os setores de oposição à condução da política econômica do governo Dilma precisavam para validar sua posição contrária.

A atuação destes setores de oposição se deu inicialmente através do perigo iminente do retorno da inflação que era expresso pelos relatórios feitos pelos próprios representantes do mercado financeiro e propagado na grande mídia. Este quadro agravou ainda mais o cenário de incerteza econômica, limitando os impulsos ao investimento produtivo privado. Com a efetiva piora dos resultados macroeconômicos, estes setores em questão passaram a formular um duro discurso anti-intervencionista, associando de maneira oportunista os fracassos da política monetária e da política macroeconômica como um todo, ao excesso de intervenção do governo na economia. Tal discurso ganhou ainda mais fôlego a partir de abril de 2013, mesmo após o início da trajetória de aumento da Selic até dezembro de 2014. A reversão da política de redução dos juros a partir de 2013 e as escolhas de Dilma para o segundo mandato que contrariavam o discurso que a elegeu, especialmente no que se refere ao nome de Joaquim Levy para a pasta da Fazenda e as políticas adotadas a partir de então, devem ser compreendidas justamente como uma tentativa de acalmar o alvoroço político criado pelos setores rentistas e financistas. 
Tudo isto considerado, um questionamento pertinente seria: qual a viabilidade em se promover uma redução expressiva da taxa de juros brasileira, altamente necessária dada a exorbitância dos juros no Brasil, de modo a evitar que se desenrole o mesmo processo verificado no governo Dilma? Em outras palavras, estaríamos vivenciando uma espécie de arapuca na redução da taxa de juros? A resposta para esta questão não encontra-se neste trabalho, mas espera-se que o mesmo possa fornecer elementos para esta e outras análises.

\section{Referências bibliográficas}

ARAÚJO, E.; ARAÚJO, E; FERRARI-FILHO, F. Monetary institutions and economic growth in Brazil after the inflation targeting regime: theoretical aspects and empirical evidence. Proceedings of the 40 Years of The Cambridge Journal of Economics Conference. 2016. Disponível em: www.cpes.org.uk/dev/wpcontent/uploads/2016/06/Ara\%C3\%BAjoAra\%C3\%BAjoFerrari_paper.pdf.

ARESTIS, P.; DE PAULA, L. F. R.; FERRARI-FILHO, F. A nova política monetária: uma análise do regime de metas de inflação no Brasil (Assessing the inflation targeting regime in Brazil). Economia e Sociedade, v. 18, n. 1, p. 35, 2009.

BARBOSA-FILHO, N. O desafio macroeconômico de 2015-2018. Revista de Economia Política, v. 35, n. 3, p. 403-425, 2015.

BECKER, J.; JAGER, J.; LEUBOLT, B.; WEISSENBACHER, R. Peripheral financialization and vulnerability to crisis: a regulationist perspective. Competition and Change, n. 14, n. 3-4, p. 225-247, 2010.

BERNANKE, B. S.; MISHKIN, F. S. Inflation targeting: a new framework for monetary policy? Journal of Economic Perspectives, v. 11, n. 2, p. 97-116, 1997.

BIANCARELLI, A. M. A Era Lula e sua questão econômica principal: crescimento, mercado interno e distribuição de renda. Revista do Instituto de Estudos Brasileiros, n. 58, p. 263-288, 2014.

BONIZZI, B. International financialisation, developing countries and the contradictions of privatised Keynesianism. Economic and Political Studies, v. 5, n. 1, 21-40, 2017.

BRESSER-PEREIRA, L. C. A construção política do Brasil: sociedade, economia e Estado desde a Independência. São Paulo: Editora 34 Ltda., 2015.

BRESSER-PEREIRA, L. C.; GOMES, C. O regime de metas de inflação no Brasil e a armadilha da taxa de juros/taxa de câmbio". In OREIRO, J. L.; DE PAULA, L. F. R.; SOBREIRA, R. (Org.). Política monetária, bancos centrais e metas de inflação. Rio de Janeiro: Editora FGV, 2009. 
BRESSER-PEIREIRA, L. C.; NAKANO, Y. A armadilha dos juros. Folha de São Paulo, São Paulo, fev. 2002.

BRUNO, M. Financeirização e crescimento econômico: o caso do Brasil. ComCiência (Unicamp), Campinas, SP, 10 maio 2011.

CAGNIN, R. F; PRATES, D. M.; FREITAS, M. C. P.; NOVAIS, L. F. A gestão macroeconômica no governo Dilma (2011 - 2012). Novos Estudos - Cebrap, São Paulo, n. 97, 2013.

CAMPEDELLI, A. L.; LACERDA, A. C. Uma crítica pós-Keynesiana ao Regime de Metas de Inflação (RMI) no Brasil. Pesquisa e Debate, São Paulo, v. 25, 2014.

CARVALHO, F. J. C. Temas de política monetária keynesiana. Ensaios FEE, v. 15, n. 1, p. 33-61, 1994.

CARVALHO, F. J. C. Uma contribuição ao debate em torno da eficácia da política monetária e algumas implicações para o caso do Brasil. In: OREIRO, J. L.; DE PAULA, L. F. R.; SOBREIRA, R. (Org.). Política monetária, bancos centrais e metas de inflação. Rio de Janeiro: Editora FGV, 2009.

CARVALHO, F. J. C; SOUZA, F. P.; SICSÚ, J.; PAULA, L. F. R.; STUDART, R. Economia monetária e financeira. 2. ed. rev. e atual. Rio de Janeiro: Campus, 2012.

DE CARVALHO, A. R. A persistência da indexação no Brasil pós-Real. Brazilian Journal of Political Economy / Revista de Economia Política, v. 34, n. 2, 2014.

DE PAULA, L. F. R. A teoria da firma bancária. In: SICSÚ, João; DE PAULA, Luiz Fernando; LIMA, Gilberto Tadeu. Macroeconomia moderna: Keynes e a economia contemporânea. Rio de Janeiro: Campus, 1999. p. 171-189.

DE PAULA, L. F. R.; SARAIVA, P. J. Novo consenso macroeconômico e regime de metas de inflação: algumas implicações para o Brasil. Revista Paranaense de Desenvolvimento-RPD, v. 36, n. 128, p. 19-32, 2015.

DEQUECH, D. Conventional and unconventional behavior under uncertainty. Journal of Post Keynesian Economics, USA, v. 26, n. 4, p. 145-168, 2003.

DEQUECH, D. Institutions, social norms, and decision-theoretic norms. Journal of Economic Behavior and Organization, v. 72, n. 1, p. 70-78, 2009.

DIEESE. Um novo cenário para o setor financeiro no Brasil. São Paulo: Dieese, 2013. (Nota Técnica, n. 123).

DUPUY, J. P. et al. L'économie des conventions. Revue Économique, v. 40, n. 2, 1989.

EPSTEIN, G. Introduction: financialization and the world economy. In: EPSTEIN, G. (Org.). Financialization and the world economy. Edward Elgar, 2005. 
ERBER, F. S. As convenções de desenvolvimento no Brasil: um ensaio de economia política. In: FÓRUM DE ECONOMIA DA FGV-SP, 5, set. 2008.

ERBER, F. S. As convenções de desenvolvimento no governo Lula: um ensaio de economia política. Revista de Economia Política, v. 31, n. 1, p. 31-55, 2011.

GOMES, C.; AIDAR, O. Metas inflacionárias, preços livres e administrados no Brasil. In: ENCONTRO NACIONAL DE ECONOMIA POLÍTICA, 10, 2005. Proceedings...

HODGSON, G. M. Institutional economics: surveying the 'old' and the 'new.' Metroeconomica, v. 44, n. 1, p. 1-28, 1993.

HODGSON, G. M. The approach of institutional economics. Journal of Economic Literature, v. 36, p. 166, Mar. 1998.

HODGSON, G. M. What are institutions? Journal of Economic Issues, v. 21, n. 1, Mar. 2006.

JODELET, D. Les représentations sociales. Paris: Presses Universitaire de France, 1989.

KARWOWSKI, E.; STOCKHAMMER, E. Financialisation in emerging economies: a systematic overview and comparison with anglo-saxon economies. Post Keynesian Economics Study Group, 2016. (Working Paper, n. 1616).

KEYNES, J. M. A teoria geral do emprego, do juro e da moeda. São Paulo Ed. Atlas, [1936] 1982.

KEYNES, J. M. The general theory of employment. The Quarterly Journal of Economics, v. 51, n. 2, p. 209-223, 1937.

LACERDA, A. C. Razões do baixo crescimento da economia brasileira no governo Dilma Rousseff. In: DOSSIÊ DA CRISE, 4, p. 142-150, 2013.

LAVOIE, M. Foundations of post Keynesian analysis. Aldershot, UK and Brookfield, US: Edward Elgar, 1992.

MANTEGA, G. O primeiro ano da nova matriz econômica. Valor Econômico, 19 dez. 2012.

MENDONÇA, H. F. Metas de inflação e taxa de juros no Brasil: uma análise do efeito dos preços livres e administrados. Revista de Economia Política, v. 27, n. 3, 2007.

MINSKY, H. La hipótesis de la inestabilidad financiera. Revista de Economía Crítica, n. 9, primeiro semestre 2010 [1992].

MINSKY, H. Stabilizing an unstable economy. New Haven: Yale University Press, 1986. 
MODENESI, A. M. Convenção e rigidez na política monetária: uma estimativa da função de reação do BCB - 2000-2007. Rio de Janeiro: Ipea, 2008. (Texto para Discussão, n. 1351).

MODENESI, A. M. Convenções do desenvolvimento: contribuição de Fabio Erber. 2013. Disponível: www.ie.ufrj.br/images/pesquisa/pesquisa/textos sem peq/ texto0907.pdf.

MODENESI, A. M.; MODENESI, R. L. Quinze anos de rigidez monetária no Brasil pós Plano Real: uma agenda de pesquisa. Revista de Economia Política, v. 32, n. 3, n. 128, p. 389-411, 2012.

MOLLO, M. L. R. A supremacia da finança e da crise. Brazilian Keynesian Review, v. 1, n. 1, p. 55-70, 2015.

NAKANO, Y. Antes que os populistas tomem conta. Valor Econômico, 17 jan. 2006.

NAKANO, Y. Finalmente a independência do BC. Valor Econômico, 13 set. 2011.

OREIRO, J. L.; DE PAULA, L. F. R. Uma agenda de reformas macroeconômicas para o crescimento sustentado com estabilidade de preços e equidade social. Revista Economia \& Tecnologia, v. 6, n. 1, 2010.

OREIRO, J. L.; DE PAULA, L. F. R.; SILVA G. J. C. D.; AMARAL, R. Q. D. Por que as taxas de juros são tão elevadas no Brasil?: uma avaliação empírica. Revista de Economia Política, v. 32, n. 4, p. 557-579, 2012.

OREIRO, J. L.; PASSOS, M. A governança da política monetária brasileira: análise e proposta de mudança. Indicadores Econômicos FEE, v. 33, n. 1, p. 157-168, 2005.

ORLÉAN, A. Pour une approche cognitive des conventions économiques. Revue Économique, p. 241-272, 1989.

PALLEY, Thomas I. Financialization: what it is and why it matters. London: Palgrave Macmillan, 2013. p. 17-40.

PAULANI, L. M. Os rumos da situação econômica do brasil. Revista Cultura e Extensão, USP, São Paulo, n. 13, Supl., p. 11-22, set. 2015.

PIRES, J. M.; GALHARDO, A. F. Caminhando em círculo: idas e vindas da política econômica do governo Dilma. Pesquisa \& Debate, São Paulo, 2011.

SEABRA, L.; DEQUECH, D. Convenções financeiras e a taxa básica de juros no Brasil: uma primeira aproximação. Revista de Economia Política, v. 33, n. 4, p. 599618, 2013.

SINGER, A. Quatro notas sobre as classes sociais nos dez anos do lulismo. Fundação Perseu Abramo \& Fundação Friedrich Ebert (Org.). Classes, 2014. 
TEIXEIRA, R. A.; PINTO, E. C. A economia política dos governos FHC, Lula e Dilma: dominância financeira, bloco no poder e desenvolvimento econômico. Economia e Sociedade, Campinas, v. 21, Número Especial, p. 909-941, dez. 2012.

TERRA, F. H. B. Uma interpretação pós-keynesiana do regime de metas de inflação: poderia a autoridade monetária ser capturada pelo sistema bancário? Revista Sociedade de Economia Política, Niterói-RJ, n. 38, jun. 2014.

TYMOIGNE, E.; WRAY, L. R. The rise and fall of money manager capitalism: Minsky's half century from world war two to the great recession. Routledge, 2013.

WRAY, L. R. A teoria do dinheiro de Keynes: uma avaliação após 70 anos. Revista de Economia, Ed. UFPR, v. 32, n. 2. p. 43-62, jul./dez. 2006. 